\title{
The Genus Rhizophora (Rhizophoraceae) in North-eastern Australia
}

\author{
N. C. Duke and J. S. Bunt \\ Australian Institute of Marine Science, \\ P.M.B. 3, M.S.O., Townsville, Qld 4810.
}

\begin{abstract}
Recent global revisions have failed to resolve difficulties in identification of the Australian Rhizophora. Presented is a field key and detailed specific descriptions of the four species found in the north-east. Classificatory analyses revealed the distinct nature of the entities and some of their associations with each other.
\end{abstract}

\section{Introduction}

Salvoza (1936) and more recently Ding Hou $(1958,1960)$ have reviewed the genus Rhizophora in global terms. Unfortunately their work was based on poorly representative herbarium material. Consequently, regional inadequacies persist. This is the case in north-eastern Queensland. Thus, an important and well-used field key developed for the Australian east coast mangroves (Jones 1971) omits a major species, $R$. Zamarckii, now recognized from our observations by Tomlinson and Womersley (1976). Even the most recent revisions, referring specifically to the Indo-Malesian and Australian species, suffer to some extent from limited field observations. Although $R$. mucronata has been noted in this region (Ding Hou 1960; Jones 1971; Tomlinson 1978) it appears to have been missed from the detailed treatments correlating herbarium revisions and field observations. The problem in Australia is due to the lack of adequate information on phenological variation, especially relating to the definitive characters which may prove unique to this region. We consider that the most recent key by Tomlinson (1978) although of great value on a global scale, does not adequately cover the Australian species. Differences in characters such as bud colour and length, leaf length, inflorescence structure, stamen number, style length and peduncle length are all significant. The existence of these differences is felt by the authors to justify the development of a key to the north-eastern Australian Rhizophora.

Mangrove productivity studies currently in progress on the Australian north-east coast have provided opportunities for, and indeed required, reliable species identification. The study reported here provides detailed comparative information for the north-eastern Australian Rhizophora and a field key to the four species now known to occur in this region.

The account is intended primarily for the field biologist or ecologist; however, herbarium material collected and held at the Australian Institute of Marine Science Herbarium (AIms) will allow further specialist attention by taxonomists. 


\section{Methods}

Study Area

Sites from the Torres Strait (the strait between Australia and New Guinea) islands to Port Clinton (Table 1 and Fig. 1), have been visited over the past 2 years. Fast rubber inflatable boats have enabled most of the tidal reaches of rivers, estuaries and bays to be covered efficiently. Aerial photography permitted precise navigation and the initial identification of the tidal forests. Sites between the Daintree River and Cape York were selected in terms of their distribution and on obvious physiographic differences, in the hope of sampling the range of tidal forest situations in the region. Areas south of the Daintree to the southern end of Hinchinbrook Island have been studied with greater intensity partly because of the environmental diversity evident but also because of their closer proximity to Hinchinbrook Island, which was the main study area. Sites south to Port Clinton have been given only casual attention.

All four species can be located conveniently within single rivers (e.g. Hull River) along the coastal strip close to Hinchinbrook Island.

\section{Observations and Measurements}

The characters of the Rhizophora species are very similar (Table 4 and Fig. 5), so that species can be easily confused when direct distinctions are made through measurements of phenotypic detail if the definitive characters are not present (or are missed). Paradoxically, however, it was established that, with practice, the Rhizophora species could be reliably distinguished from a distance on tree foliage and habit. Thus less definitive factors seem to combine to give a specific character to trees of each species. To make use of these less definitive characters and to validate the field observations, a classificatory analysis was attempted on trees of a known species (identified with the definitive characters as described later). A range of reproductive and vegetative characters from a selection of sites were measured. The primary outcome of the analyses was that individual species clearly showed up consistently. In addition, species relationships and some interspecific character affinities were shown.

Populations of Rhizophora have been observed at all sites listed in Table 1. Comprehensive samples were taken at eight of the locations visited including four on Hinchinbrook Island, namely Coral Creek, Wide Creek, Bowen Creek and Deluge Inlet; and one each at Shallow Bay, Jacky Jacky Creek, Claudie River and Hull River (Fig. 1). Advice from P. B. Tomlinson in 1975 initiated this study through measurement of at least four characters of the flower parts (i.e. 9, 10, 12 and 13 in Table 2) from the majority of the site samples. Later it was decided to expand the study by measuring the dimensions of the mature hypocotyl $*$ and expended fruit $\dagger$ (i.e. 15, 16 and 18-22 in Table 2). The number of phenological measurements in the field was increased to 18 , not including the calculation of significant ratios. The selected characters with brief descriptions are listed in Table 2, and the sites sampled in Table 3. For practical reasons, it was not possible to obtain complete data sets from all locations visited. Identification was achieved initially by comparison with the available keys as well as through direct consultation with P. B. Tomlinson, and

* Hypocotyls were taken as being mature when the propagules could be dislodged by a gentle shaking of the branch on which they were attached.

$\dagger$ 'Expended fruit' here refers to the full-grown fruit (Guppy 1906) when the seedling has just detached from the parent tree. The cotyledonary body is included as part of the expended fruit (Fig. 6). 
finally by consideration of certain more or less definitive characters selected on the basis of experience. All 18 characters have been drawn upon in this study. For each

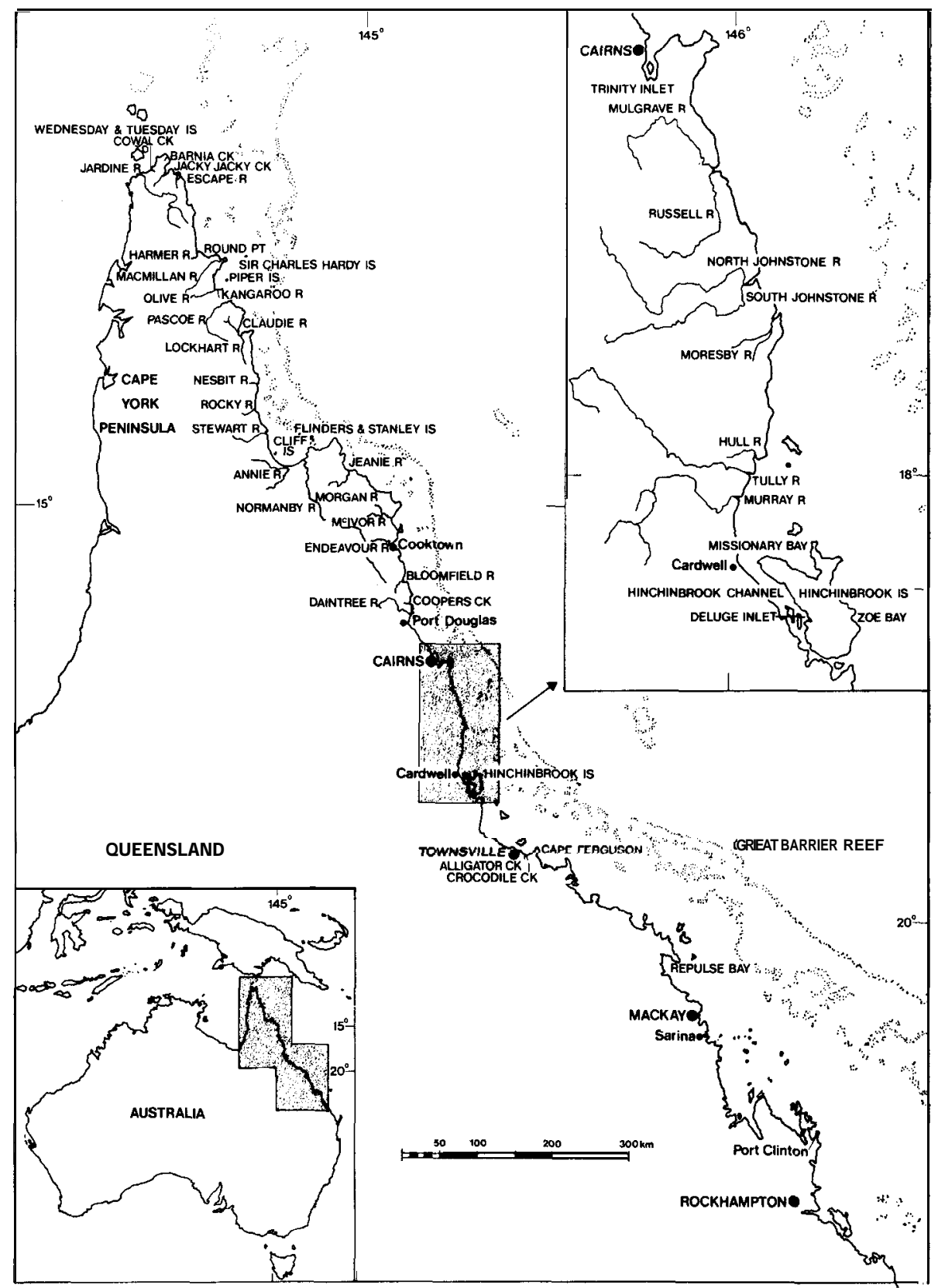

Fig. 1. Map of the locations visited duringthe course of the study.

population sampled, at least 30 character measurements were taken from one or two individual trees. 
Table 1. Locations visited (Fig. 1), with latitudes, in the study are and Rhizophora species found Observations of each species are listed as present $(\mathrm{P})$, no sighting $(\mathrm{A})$, and no sighting but low numbers expected (?); C, phenological measurements taken; S, herbarium voucher specimens held at AIMS . Gross annual mean (30 years) rainfall (Mumme 1969) shown roughly as: L (up to $1900 \mathrm{~mm}$ ), M (1901-2900 mm), and H (2901 mm and higher)

\begin{tabular}{|c|c|c|c|c|c|c|}
\hline \multirow[t]{2}{*}{ Location } & \multirow{2}{*}{$\begin{array}{l}\text { Lat. } \\
\text { (S.) }\end{array}$} & \multirow[t]{2}{*}{ Rainfall } & \multirow{2}{*}{\multicolumn{2}{|c|}{$\begin{array}{l}\text { Rhizophora } \\
\text { Rl }\end{array}$}} & \multicolumn{2}{|l|}{ speciesA } \\
\hline & & & & & Rs & $\mathrm{Rm}$ \\
\hline Jardine River & $10^{\circ} 55^{\prime}$ & $\mathrm{L}$ & $\mathrm{P}$ & $?$ & $\mathrm{P}$ & $\mathrm{P}$ \\
\hline Cowal Creek & $10^{\circ} 54^{\prime}$ & $\mathrm{M}$ & $\mathrm{P}$ & $\mathrm{P}, \mathrm{S}$ & $\mathrm{P}$ & $\mathrm{P}, \mathrm{S}$ \\
\hline Wednesday Island & $10^{\circ} 31^{\prime}$ & $\mathrm{L}$ & $\mathrm{P}$ & A & $\mathrm{P}$ & A \\
\hline Tuesday Island & $10^{\circ} 30^{\prime}$ & $\mathrm{L}$ & A & A & $\mathrm{P}$ & A \\
\hline Barnia Creek & $10^{\circ} 43^{\prime}$ & M & $\mathrm{P}, \mathrm{C}$ & $\mathrm{P}$ & $\mathrm{P}$ & $\mathrm{P}, \mathrm{S}$ \\
\hline Jacky Jacky Creek & $10^{\circ} 52^{\prime}$ & $\mathrm{L}$ & $\mathrm{P}, \mathrm{C}$ & $\mathrm{P}, \mathrm{C}, \mathrm{S}$ & $\mathrm{P}, \mathrm{C}$ & A \\
\hline Escape River & $10^{\circ} 59^{\prime}$ & $\mathrm{L}$ & $\mathrm{P}$ & $\mathrm{P}$ & $\mathrm{P}$ & A \\
\hline Harmer Creek & $11^{\circ} 55^{\prime}$ & $\mathrm{L}$ & $\mathrm{P}$ & $\mathrm{P}$ & $\mathrm{P}$ & $\mathrm{P}$ \\
\hline Round Point (creek) & $11^{\circ} 54^{\prime}$ & $\mathrm{L}$ & $\mathrm{P}$ & $?$ & $\mathrm{P}$ & A \\
\hline Macmillan River & $11^{\circ} 55^{\prime}$ & $\mathrm{L}$ & $\mathrm{P}$ & $\mathrm{P}$ & $\mathrm{P}$ & A \\
\hline Sir Charles Hardy I. & $11^{\circ} 55^{\prime}$ & $\mathrm{L}$ & A & A & $\mathrm{P}$ & A \\
\hline Olive River & $12^{\circ} 10^{\prime}$ & M & $\mathrm{P}$ & $\mathrm{P}, \mathrm{S}$ & $\mathrm{P}$ & $\mathrm{P}$ \\
\hline Piper Island & $12^{\circ} 15^{\prime}$ & $\mathrm{M}$ & A & A & $\mathrm{P}$ & A \\
\hline Kangaroo River & $12^{\circ} 22^{\prime}$ & $\mathrm{L}$ & $\mathrm{P}, \mathrm{S}$ & $\mathrm{P}$ & $\mathrm{P}$ & A \\
\hline Pascoe River & $12^{\circ} 31^{\prime}$ & M & $\mathrm{P}$ & $?$ & $\mathrm{P}, \mathrm{S}$ & $\mathrm{P}$ \\
\hline Claudie River & $12^{\circ} 50^{\prime}$ & M & $\mathrm{P}, \mathrm{C}$ & $\mathrm{P}$ & $\mathrm{P}, \mathrm{C}$ & $\mathrm{P}, \mathrm{C}$ \\
\hline Lockhart River & $12^{\circ} 52^{\prime}$ & $\mathrm{L}$ & $\mathrm{P}, \mathrm{S}$ & $\mathrm{P}$ & $\mathrm{P}$ & $\mathrm{P}$ \\
\hline Nesbit River & $13^{\circ} 33^{\prime}$ & $\mathrm{L}$ & $\mathrm{P}$ & A & $\mathrm{P}$ & A \\
\hline Rocky River & $13^{\circ} 48^{\prime}$ & $\mathrm{L}$ & $\mathrm{P}$ & $?$ & $\mathrm{P}$ & A \\
\hline Stewart River & $14^{\circ} 04^{\prime}$ & $\mathrm{L}$ & $\mathrm{P}$ & $?$ & $\mathrm{P}$ & A \\
\hline Cliff Island (east) & $14^{\circ} 13^{\prime}$ & $\mathrm{L}$ & A & A & $\mathrm{P}$ & A \\
\hline Annie River & $14^{\circ} 29^{\prime}$ & $\mathrm{L}$ & A & A & $\mathrm{P}$ & A \\
\hline Normanby River & $14^{\circ} 25^{\prime}$ & $\mathrm{L}$ & A & A & $\mathrm{P}$ & A \\
\hline Stanley Island & $14^{\circ} 09^{\prime}$ & $\mathrm{L}$ & A & A & $\mathrm{P}$ & A \\
\hline Flinders Island & $14^{\circ} 11^{\prime}$ & $\mathrm{L}$ & $\mathrm{P}$ & $\mathrm{P}, \mathrm{S}$ & $\mathrm{P}$ & A \\
\hline Jeanie River & $14^{\circ} 40^{\prime}$ & $\mathrm{L}$ & A & A & $\mathrm{P}$ & A \\
\hline McIvor/Morgan River & $15^{\circ} 11^{\prime}$ & $\mathrm{L}$ & $\mathrm{P}$ & $\mathrm{P}$ & $\mathrm{P}$ & $\mathrm{P}$ \\
\hline Endeavour River & $15^{\circ} 28^{\prime}$ & $\mathrm{L}$ & $\mathrm{P}$ & $\mathrm{P}$ & $\mathrm{P}$ & $\mathrm{P}$ \\
\hline Annan River & $15^{\circ} 31^{\prime}$ & M & $?$ & $?$ & $\mathrm{P}$ & $\mathrm{P}$ \\
\hline Bloomfield River & $15^{\circ} 55^{\prime}$ & M & $\mathrm{P}$ & $?$ & $\mathrm{P}$ & $\mathrm{P}$ \\
\hline Coopers Creek & $16^{\circ} 10^{\prime}$ & M & $\mathrm{P}$ & $\mathrm{P}, \mathrm{S}$ & $\mathrm{P}, \mathrm{S}$ & $\mathrm{P}, \mathrm{S}$ \\
\hline Daintree River & $16^{\circ} 16^{\prime}$ & M & $\mathrm{P}, \mathrm{S}$ & $\mathrm{P}$ & $\mathrm{P}, \mathrm{S}$ & $\mathrm{P}, \mathrm{S}$ \\
\hline Port Douglas & $16^{\circ} 28^{\prime}$ & M & $\mathrm{P}$ & ? & $\mathrm{P}$ & A \\
\hline Trinity Inlet & $16^{\circ} 55^{\prime}$ & M & $\mathrm{P}$ & $\mathrm{P}$ & $\mathrm{P}$ & $\mathrm{P}$ \\
\hline Mulgrave River & $17^{\circ} 14^{\prime}$ & $\mathrm{H}$ & $\mathrm{P}$ & $?$ & $\mathrm{P}$ & $\mathrm{P}$ \\
\hline Russel River & $17^{\circ} 14^{\prime}$ & $\mathrm{H}$ & $\mathrm{P}$ & $?$ & $\mathrm{P}$ & $\mathrm{P}$ \\
\hline Johnstone River & $17^{\circ} 31^{\prime}$ & $\mathrm{H}$ & $\mathrm{P}$ & $?$ & $\mathrm{P}$ & $\mathrm{P}$ \\
\hline Moresby River & $17^{\circ} 36^{\prime}$ & $\mathrm{M}$ & $\mathrm{P}$ & $\mathrm{P}$ & $\mathrm{P}$ & $\mathrm{P}$ \\
\hline Hull River & $17^{\circ} 59^{\prime}$ & M & $\mathrm{P}, \mathrm{C}, \mathrm{S}$ & $\mathrm{P}, \mathrm{C}, \mathrm{S}$ & $\mathrm{P}, \mathrm{C}, \mathrm{S}$ & $\mathrm{P}, \mathrm{C}, \mathrm{S}$ \\
\hline Tully River & $18^{\circ} 02^{\prime}$ & $\mathrm{H}$ & $\mathrm{P}$ & $?$ & $\mathrm{P}$ & $\mathrm{P}, \mathrm{S}$ \\
\hline Murray River & $18^{\circ} 05^{\prime}$ & M & $\mathrm{P}$ & $?$ & $\mathrm{P}$ & $\mathrm{P}$ \\
\hline Hinchinbrook Channel & $18^{\circ} 15^{\prime}-31^{\prime}$ & $\mathrm{M}$ & $\mathrm{P}, \mathrm{S}$ & $\mathrm{P}, \mathrm{S}$ & $\mathrm{P}$ & A \\
\hline Missionary Bay & $18^{\circ} 15^{\prime}$ & M & $\mathrm{P}, \mathrm{C}, \mathrm{S}$ & $\mathrm{P}, \mathrm{C}, \mathrm{S}$ & $\mathrm{P}, \mathrm{C}, \mathrm{S}$ & A \\
\hline Zoe Bay & $18^{\circ} \quad 23^{\prime}$ & M & $\mathrm{P}$ & $\mathrm{P}$ & $\mathrm{P}, \mathrm{S}$ & A \\
\hline Deluge Inlet & $18^{\circ} 25^{\prime}$ & M & $\mathrm{P}, \mathrm{C}$ & $\mathrm{P}, \mathrm{C}, \mathrm{S}$ & $\mathrm{P}, \mathrm{C}, \mathrm{S}$ & $\mathrm{P}, \mathrm{C}, \mathrm{S}$ \\
\hline Townsville (near) & $19^{\circ} 16^{\prime}$ & $\mathrm{L}$ & $?$ & A & $\mathrm{P}, \mathrm{S}$ & A \\
\hline Alligator Creek & $19^{\circ} 18^{\prime}$ & $\mathrm{L}$ & A & A & $\mathrm{P}$ & A \\
\hline
\end{tabular}


Table 1 (Continued)

\begin{tabular}{lllllll}
\hline \multicolumn{1}{c}{ Location } & Lat. & Rainfall & \multicolumn{3}{c}{ Rhizophora $^{\text {species }}$} \\
& (S.) & & Ra & Rl & Rs & Rm \\
\hline Crocodile Creek & $19^{\circ} 17^{\prime}$ & $\mathrm{L}$ & $\mathrm{A}$ & $\mathrm{A}$ & $\mathrm{P}$ & $\mathrm{A}$ \\
Cape Ferguson & $19^{\circ} 17^{\prime}$ & $\mathrm{L}$ & $\mathrm{P}, \mathrm{S}$ & $\mathrm{A}$ & $\mathrm{P}, \mathrm{S}$ & $\mathrm{A}$ \\
Repulse Bay & $20^{\circ} 27^{\prime}$ & $\mathrm{M}$ & $\mathrm{P}$ & $\mathrm{P}$ & $\mathrm{P}$ & $\mathrm{A}$ \\
Mackay & $21^{\circ} 18^{\prime}$ & $\mathrm{L}$ & $\mathrm{P}$ & $?$ & $\mathrm{P}$ & $\mathrm{A}$ \\
Sarina & $21^{\circ} 24^{\prime}$ & $\mathrm{M}$ & $\mathrm{P}$ & $?$ & $\mathrm{P}$ & $\mathrm{A}$ \\
Port Clinton & $22^{\circ} 30^{\prime}$ & $\mathrm{L}$ & $\mathrm{P}$ & $\mathrm{P}, \mathrm{S}$ & $\mathrm{P}$ & $\mathrm{A}$ \\
\hline
\end{tabular}

A Ra, apiculata; R1, lamarckii; Rs, stylosa; Rm, mucronata.

Table 2. Characters used for classificatory analyses and specific descriptions Summation of character groups as noted in the text: leaf characters (1-5); characters of buds and flowers (6-14); characters of expended fruit and hypocotyls (15-23)

\begin{tabular}{rll}
\hline \multicolumn{1}{c}{ Character } & \multicolumn{1}{c}{ Description } \\
\hline 1 & Leaf L & Blade length \\
2 & Leaf W & Widest width \\
3 & Leaf L/W & Leaf (length/width) ratio \\
4 & Petiole L & Overall straight length \\
5 & Leaf mucro L & Mature intact length \\
6 & Bud L & Mature, bract base to tip, length \\
7 & Bud W & Widest width \\
8 & Bud L/W & Bud (length/width) ratio \\
9 & Peduncle L & Overall straight length \\
10 & Peduncle W & Mid section, width \\
11 & Peduncle L/W & Peduncle (length/width) ratio \\
12 & Inflorescence branch N & Dichotomous branch points \\
13 & Stamen N & Number of developed stamens \\
14 & Style L & Length, ovary base to tip \\
15 & Expended (ex) fruit L & Calyx lobe base to tip, length \\
16 & Expended fruit W & Widest width \\
17 & Expended fruit L/W & Expended fruit (length/width) ratio \\
18 & Expended fruit peduncle L & Overall straight length \\
19 & Expended fruit peduncle W & Mid section, width \\
20 & Hypocotyl L & Shoot to root tip, length \\
21 & Hypocotyl collar W & Rim diameter at shoot base \\
22 & Hypocotyl W & Widest width \\
23 & Hypocotyl L/W & Hypocotyl (length/width) ratio \\
\hline
\end{tabular}

Table 3. Sites of collection for classificatory analyses and specific descriptions

\begin{tabular}{ll}
\hline & \multicolumn{1}{c}{ Site locations } \\
\hline A & Barnia Creek, Shallow Bay \\
B & Jacky Jacky Creek \\
C & Claudie River \\
D & Hull River \\
E & Coral Creek, Missionary Bay \\
F & Wide Creek, Missionary Bay \\
G & Bowen Creek, Missionary Bay \\
H & Deluge Inlet \\
\hline
\end{tabular}




\section{Classificatory Analysis}

Observation of the variation of any particular character in Rhizophora, such as peduncle length, shows that there is quite often overlap between species. Thus these characters can be described as non-definitive. Simultaneous evaluation of a number of these characters is necessary to group populations according to species. Data obtained from the phenological measurements of several populations were subjected to classificatory techniques (Gower and Ross 1969; Williams 1971).

Table 4. Mean measurements (cm) for Rhizophora species, with \{range\} and [number of components measured]

\begin{tabular}{|c|c|c|c|c|}
\hline Character & R. apiculata & R. lamarckii & R. stylosa & R. mucronata \\
\hline Leaf L & $\begin{array}{l}13 \cdot 04[107] \\
\{7 \cdot 9-19 \cdot 0\}\end{array}$ & $\begin{array}{l}11.36[80] \\
\{7 \cdot 7-14 \cdot 8\}\end{array}$ & $\begin{array}{l}9.98[100] \\
\{6.3-13.7\}\end{array}$ & $\begin{array}{c}13.25[40] \\
\{10.5-16.5\}\end{array}$ \\
\hline Leaf W & $\begin{array}{r}6.48[107] \\
\{3.9-8.8\}\end{array}$ & $\begin{array}{l}5.81[80] \\
\{3.2-8.2\}\end{array}$ & $\begin{array}{l}5.78[100] \\
\{3.8-8.0\}\end{array}$ & $\begin{array}{c}7.39[40] \\
\{5.1-10.6\}\end{array}$ \\
\hline Petiole L & $\begin{array}{l}2.45[107] \\
\{1.1-3.9\}\end{array}$ & $\begin{array}{l}2.48[80] \\
\{1.2-3.5\}\end{array}$ & $\begin{array}{l}2.37[100] \\
\{1.3-3.6\}\end{array}$ & $\begin{array}{c}3.11[40] \\
\{2.2-4.1\}\end{array}$ \\
\hline Leaf mucro L & $\begin{array}{l}0.37[100] \\
\{0.2-0.6\}\end{array}$ & $\begin{array}{l}0.44[70] \\
\{0.3-0.6\}\end{array}$ & $\begin{array}{l}0.37[100] \\
\{0.2-0.6\}\end{array}$ & $\begin{array}{l}0.36[33] \\
\{0.2-0.5\}\end{array}$ \\
\hline Stipule L $^{\mathrm{A}}$ & $\begin{array}{r}6.98[29] \\
\{4.6-8.5\}\end{array}$ & $\begin{array}{l}5.99[35] \\
\{3.7-8.4\}\end{array}$ & $\begin{array}{l}4.57[49] \\
\{2.6-6.4\}\end{array}$ & $\begin{array}{l}6.76[13] \\
\{5.8-7.9\}\end{array}$ \\
\hline Bud L & $\begin{array}{l}1.37[100] \\
\{1.1-1.6\}\end{array}$ & $\begin{array}{l}1.48[70] \\
\{1.1-1.7\}\end{array}$ & $\begin{array}{l}1.52[102] \\
\{1.3-1.8\}\end{array}$ & $\begin{array}{l}1.50[33] \\
\{1.2-1.8\}\end{array}$ \\
\hline Bud W & $\begin{array}{l}1.04[100] \\
\{1.0-1.3\}\end{array}$ & $\begin{array}{c}0.96[70] \\
\{0.7-1.2\}\end{array}$ & $\begin{array}{c}0.78[102] \\
\{0.7-0.9\}\end{array}$ & $\begin{array}{r}0.79[33] \\
\{0.7-1.0\}\end{array}$ \\
\hline Style L & $\begin{array}{l}0.09[106] \\
\{0.05-0.1\}\end{array}$ & $\begin{array}{r}0.19[75] \\
\{0.1-0.3\}\end{array}$ & $\begin{array}{l}0.42[114] \\
\{0.3-0.55\}\end{array}$ & $\begin{array}{c}0.11[44] \\
\{0.06-0.2\}\end{array}$ \\
\hline Peduncle L & $\begin{array}{l}0.97[307] \\
\{0.3-2.1\}\end{array}$ & $\begin{array}{l}1.78[130] \\
\{0.8-3.0\}\end{array}$ & $\begin{array}{l}2.73[365] \\
\{1.2-4.8\}\end{array}$ & $\begin{array}{l}3.45[229] \\
\{1.2-6.6\}\end{array}$ \\
\hline Peduncle W & $\begin{array}{l}0.51[307] \\
\{0.4-0.7\}\end{array}$ & $\begin{array}{l}0.42[130] \\
\{0.3-0.5\}\end{array}$ & $\begin{array}{l}0.30[365] \\
\{0.2-0.4\}\end{array}$ & $\begin{array}{c}0.32[229] \\
\{0.2-0.5\}\end{array}$ \\
\hline Fruit ex L & $\begin{array}{l}2.24[104] \\
\{1.8-2.7\}\end{array}$ & $\begin{array}{l}2.61[4] \\
\{2.4-3.0\}\end{array}$ & $\begin{array}{l}3.52[114] \\
\{2.7-4.8\}\end{array}$ & $\begin{array}{r}5.10[85] \\
\{3.4-6.0\}\end{array}$ \\
\hline Fruit ex W & $\begin{array}{l}2.06[104] \\
\{1.7-2.4\}\end{array}$ & $\begin{array}{l}1.93[4] \\
\{1.8-2.1\}\end{array}$ & $\begin{array}{l}2.67[114] \\
\{2.1-3.2\}\end{array}$ & $\begin{array}{r}3.16[85] \\
\{1.9-3.7\}\end{array}$ \\
\hline Hypocotyl L & $\begin{array}{l}28.2[104] \\
\{20-37\}\end{array}$ & $\begin{array}{l}18.7[4] \\
\{14-28\}\end{array}$ & $\begin{array}{c}42.0[116] \\
\{26-65\}\end{array}$ & $\begin{array}{l}58.7[79] \\
\{40-80\}\end{array}$ \\
\hline Hypocotyl W & $\begin{array}{l}1.68[104] \\
\{1.2-2.0\}\end{array}$ & $\begin{array}{l}1.20[4] \\
\{1.0-1.3\}\end{array}$ & $\begin{array}{l}1.58[116] \\
\{1.2-2.1\}\end{array}$ & $\begin{array}{l}1.69[79] \\
\{1.2-2.1\}\end{array}$ \\
\hline Collar W & $\begin{array}{l}0.80[104] \\
\{0.6-0.9\}\end{array}$ & $\begin{array}{c}0.73[4] \\
\{0.6-0.9\}\end{array}$ & $\begin{array}{l}1.07[116] \\
\{0.8-1.4\}\end{array}$ & $\begin{array}{l}1.02[79] \\
\{0.8-1.2\}\end{array}$ \\
\hline
\end{tabular}

A Stipule L: interpetiolar stipule (or leaf sheath) length. This character was not used in the analysis.

Populations of the species were classified from several groups of data by using the Euclidean analysis of Burr $(1968,1970)$. The attributes were standardized to bring them to equal variance, then the metric was used as a distance measure and sorted to minimize the incremental sum of squares. The matrix of the distances was also used for computing 'minimum spanning tree' values for the components measured. 
The programs* included: mulclas, minspan, and Grouper.

Data groups analysed included the following.

(1) Total set of characters (all except the ratios, 3, 8, 11, 17 and 23, in Table 2), numbering 18 , from three sites $(\mathrm{D}, \mathrm{E}, \mathrm{G}$ in Table 3), representing seven distinct populations (Fig. 2b).

(2) Leaf characters (including 1-5 in Table 2), numbering five, from four sites (D-G in Table 3), representing 13 distinct populations (Fig. 3a).

(3) Characters of the flower I (including 9-13 in Table 2), numbering five, from seven sites (A-E, $\mathrm{G}$ and $\mathrm{H}$ in Table 3), representing 27 distinct populations.

Table 5. Approximate measures ( $\mathrm{mm}$ ) and subjective characters noted in the study area for Rhizophora

\begin{tabular}{|c|c|c|c|c|c|}
\hline \multicolumn{2}{|c|}{ Character } & \multirow{2}{*}{$\begin{array}{l}\quad R \text {. apiculata } \\
\text { elliptic } \\
\text { darkish green } \\
\text { none }\end{array}$} & \multirow{2}{*}{$\begin{array}{l}\text { R. lamarckii } \\
\text { elliptic } \\
\text { yellow-green } \\
\text { none }\end{array}$} & \multirow{2}{*}{$\begin{array}{l}\quad R \text {. stylosa } \\
\text { obovate } \\
\text { yellow-green } \\
\text { red-brown }\end{array}$} & \multirow{2}{*}{$\begin{array}{l}R . \text { mucronata } \\
\text { obovate } \\
\text { bright green } \\
\text { red-brown }\end{array}$} \\
\hline Leaves: & $\begin{array}{l}\text { shape } \\
\text { colour } \\
\text { spots }\end{array}$ & & & & \\
\hline Bark : & $\begin{array}{l}\text { colour } \\
\text { texture }\end{array}$ & $\begin{array}{l}\text { black to grey } \\
\text { smooth to rough }\end{array}$ & $\begin{array}{l}\text { brown to grey } \\
\text { rough }\end{array}$ & $\begin{array}{l}\text { red to grey } \\
\text { smooth to rough }\end{array}$ & $\begin{array}{l}\text { dark brown } \\
\text { very rough }\end{array}$ \\
\hline Petal : & $\begin{array}{l}\text { length } \\
\text { width } \\
\text { shape } \\
\text { margin } \\
\text { number }\end{array}$ & $\begin{array}{l}\quad \sim 9.2 \\
\quad \sim 2.1 \\
\text { oblong } \\
\text { glabrous } \\
\qquad 4\end{array}$ & $\begin{array}{c}\quad \sim 9.7 \\
\sim 3.2 \\
\text { lanc./oblong } \\
\text { tomentose } \\
\qquad(3-) 4\end{array}$ & $\begin{array}{l}\qquad 12.0 \\
\qquad 3.6 \\
\text { lanceolate } \\
\text { villous } \\
\qquad(3-) 4\end{array}$ & 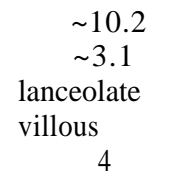 \\
\hline Stamens: & number & $(9-) 11-12(-15)$ & $(7-) 8-11(15)$ & $(6-) 8$ & $(7-) 8$ \\
\hline Bracts : & $\begin{array}{l}\text { shape } \\
\text { surface }\end{array}$ & $\begin{array}{l}\text { bulbous } \\
\text { rough, fissured }\end{array}$ & $\begin{array}{l}\text { sturdy } \\
\text { smooth }\end{array}$ & $\begin{array}{l}\text { regular } \\
\text { smooth }\end{array}$ & $\begin{array}{l}\text { minute } \\
\text { smooth }\end{array}$ \\
\hline Inflor. bran & h no. & $1(-2)$ & (0-)1-2 & $(0-) 2-4(-6)$ & $0-1(-2)$ \\
\hline Fruit ex: & $\begin{array}{l}\text { shape } \\
\text { surface }\end{array}$ & $\begin{array}{l}\text { cork-like } \\
\text { rough }\end{array}$ & $\begin{array}{l}\text { pyriform } \\
\text { coriaceous }\end{array}$ & $\begin{array}{l}\text { pyriform } \\
\text { coriaceous }\end{array}$ & $\begin{array}{l}\text { pyriform } \\
\text { coriaceous }\end{array}$ \\
\hline Hypocotyl & root tip & blunt & rounded & pointed & pointed \\
\hline
\end{tabular}

(4) Characters of the flower II (including 9-14 in Table 2), numbering six, from five sites (A, D, E, $\mathrm{G}$ and $\mathrm{H}$ in Table 3), representing 18 distinct populations (Fig. 3b).

(5) Characters of the buds and flowers (including 6-14 (except 11) in Table 2), numbering eight, from four sites (D, E, G, $\mathrm{H}$ in Table 3) representing 11 distinct populations (Fig. 2a).

(6) Characters of the expended fruit and hypocotyls (including 15-17 and 20-23 in Table 2), numbering seven, from five sites (D-H in Table 3), representing 14 distinct populations (Fig. 3c).

\section{Results}

\section{Species Recognition and Development of Key}

The first species identified ( $R$. apiculata) was noted in Missionary Bay on Hinchinbrook IsIand (Fig. I) where this study commenced. CIassificatory analysis

* Programs on the CSIRO net, which were run by Dr W. T. Williams (Davies Laboratory, CSIRO, Townsville) who chose them and provided the necessary expertise for interpretation of the processed data. 
has shown that this species varies relatively little from one population to another in all characters studied except leaf dimensions (Fig. 3a). R. apiculata is also shown to be distinct from other Rhizophora when characters of the buds and flowers are considered (Fig. 2a). The second species identified was $R$. stylosa which, according

(a)

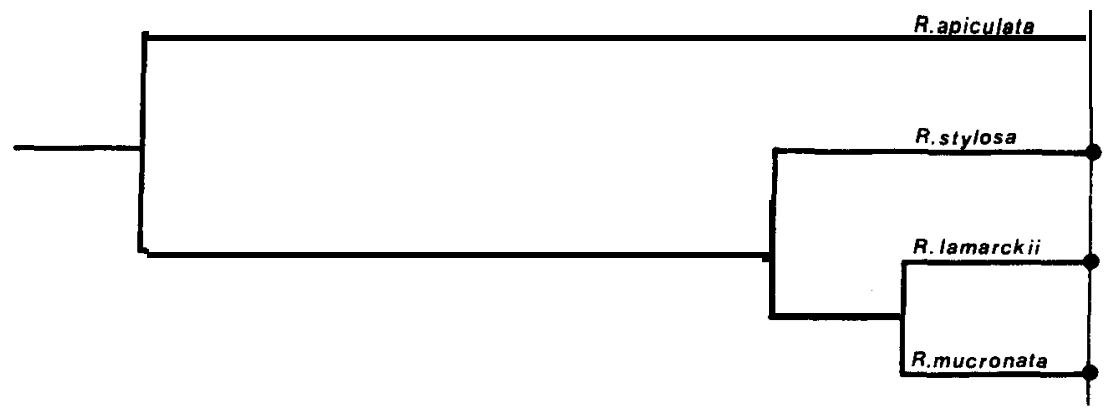

(b)

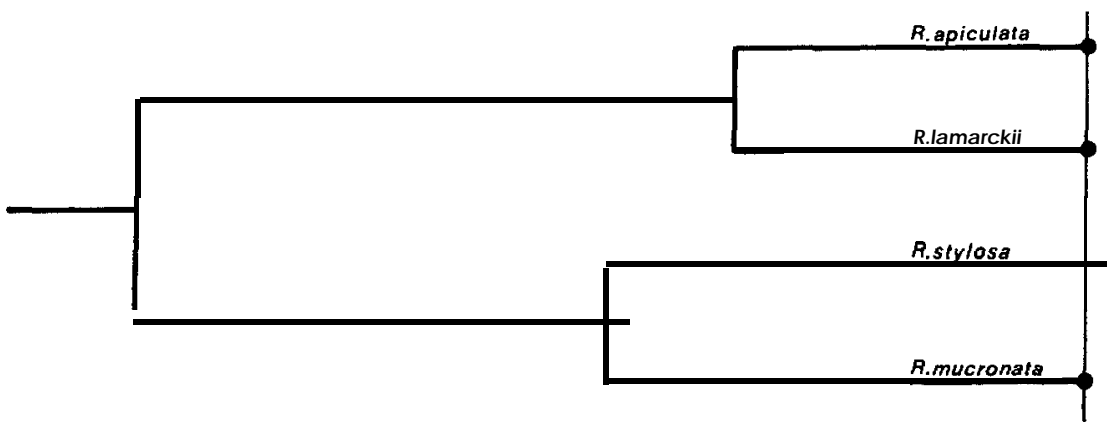

Fig. 2. Two mULCLAS analyses in the form of hierarchical diagrams of groups of different populations of Rhizophora species. Junction points have been scaled according to the relative order of similarity of the fusion of the groups in the analyses. The two analyses concentrate on different component groups: $(a)$ characters of the buds and flowers (data group 5); (b) total set of characters studied (data group 1).

to classificatory analysis, bears the least similarity to $R$. apiculata. A third entity was found commonly, even to dominance in some stands. Characters such as the absence of reddish brown spots (i.e. conspicuous cork warts*) on the leaf undersurface (similar to $R$. apiculata and not to the other species), mostly a single and double dichotomous inflorescence structure ( $R$. apiculata almost always has only single,

* Cork warts appear to be corked epithem cells (Ding Hou 1958) and resemble small glands on the leaf undersurface. In regard to some descriptive accounts these structures have been described in a variety of terms and colours (e.g. Salvoza 1936; Ding Hou 1958; Jones 1971; Semeniuk et al. 1978). When conspicuous, they have the appearance of small spots or dots evenly scattered over, and flush with, the leaf undersurface. Colour varies, depending on whether the leaves are fresh (or living), when they are usually reddish brown; if dried, they are usually brownish black. The description in this report has been adopted for the benefit of the field observer.

The absence of conspicuous cork warts from two Queensland Rhizophoras appears contrary to the findings of Stace (1966) and Ding Hou (1958). Both of these authors noted that all Rhizophora species and often even other Rhizophoraceae possess these structures. 
$R$. stylosa has two to three commonly, and $R$. mucronata has zero to single dichotomy commonly; Fig. 4), low fertility, moderate style length (comparable with none of the others, Fig. 5), and other characteristics gave this form considerable individuality.
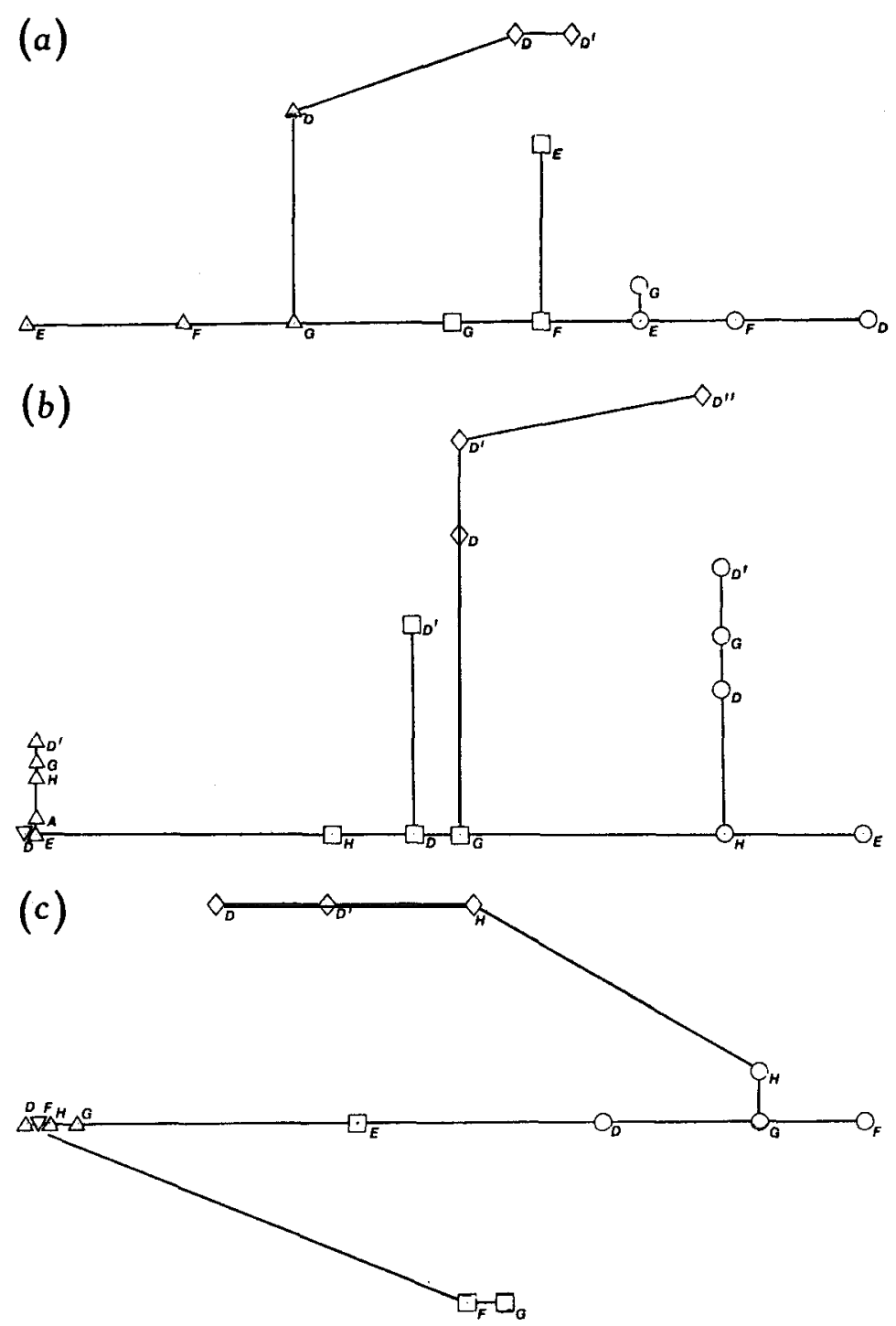

Fig. 3. Three MINSPAN analyses of groups of different populations of Rhizophora species showing closest affinities. Lettering refers to sites listed in Table 3. The three analyses concentrate on different component groups: (a) leaf characters (data group 2); (b) characters of the flowers II (data group 4); (c) characters of the expended fruit and hypocotyls (data group 6).

Í R. apiculata; ${ }^{\circ}$ R. Zamarckii; $\leq$ R. mucronata; ${ }^{\circ}$ R. stylosa.

P. B. Tomlinson confirmed that this entity was referable to $R$. lamarckii, previously known only from New Caledonia, which has a slightly different form from the Australian species. Classificatory analysis showed that in all the characters studied, 
except possibly for the expended fruit and hypocotyls ( $R$. lamarckii because of its low hypocotyl set was poorly represented in the analysis), the species was intermediate between $R$. apiculata and $R$. stylosa (Fig. $3 a, 3 b$ ). This study provides further evidence for the theory of the 'recent' hybrid origin of the species as suggested in the literature (Tomlinson and Womersley 1976).

A fourth species was found nearby in the Hull River. We consider it referable to $R$. mucronata, although it bore some marked differences (both in morphology and in local distribution) to the Indo-Malesian descriptions of the species. Furthermore, this species had a character which, to our knowledge, is unreported elsewhere, viz. inflorescences with one or two pedicels and one sessile flower attached to the same peduncle ( $1 a$ and $1 b$ in Fig. 4). This character was quite common. Classificatory analysis demonstrated that the association of this species with others was extremely variable, depending very much on which characters were studied. When leaves were considered $R$. mucronata, although distinct from the others, was most closely associated with $R$. apiculata (Fig. $3 a$ ). When characters of the buds and flowers were considered, the species was associated most closely with $R$. lamarckii (Figs $2 a, 3 b$ ). Finally, when characters of the expended fruit and hypocotyls were considered, the species was most closely associated with $R$. stylosa (Fig. $3 c$ ). On consideration of all characters studied, $R$. mucronata was associated most closely with $R$. stylosa as a member of the Mangle group (Salvoza 1936). The association was not, however, as strong as that between $R$. apiculata and $R$. lamarckii which make up the Aërope group. These associations were found to hold with all character groups analysed (Fig. $2 b$ ), except bud dimensions (Fig. 2a) and leaf measurements.

Extensive field observations showed that the character of spots on the leaf undersurface (present in $R$. mucronata and $R$. stylosa and absent from $R$. apiculata and $R$. lamarckii) was consistent along the entire north-east Australian coast. This character, along with style length (Table 4 and Fig. 5), suffices to distinguish these Rhizophora. However, the key has been enlarged with other characters (including those summarized in Table 5) to allow the exact identification of material which is either incomplete for various reasons (possibly uncoordinated flowering periods) or damaged.

\section{Field Key to the Rhizophora of North-eastern Australia}

Observations and measurements were all made on fresh material.

A. Leaves without spots on the undersurface.

Leaf blade usually elliptic, length to width $(\mathrm{L} / \mathrm{W})$ ratio $c .2 .00$; peduncle length usually less than $2 \mathrm{~cm}$, often shorter than the petioles in the same leafy crown; bud shape oval or elliptic, L/W ratio $c$. 1.45 ; stamens 8 to 12 , commonly; petals either oblong or lanceolate, glabrous or slightly hairy, and flat or slightly involute; calyx lobes thick and angular; bracts and bracteoles smooth or rough-surfaced, always relatively sturdy; hypocotyls usually less than $35 \mathrm{~cm}$ long, quite often having a rounded or blunt root tip; hypocotyl collar width $6.0-8.5(\tilde{x}=8.0) \mathrm{mm}$

.B. Rhizophora subgroup: Aërope

B. Style length $0.5-1.3(\tilde{x}=0.9) \mathrm{mm}$; bracts and bracteoles bulbous and roughly fissured.

Petals glabrous flat and oblong; stamens (9-)11-12(-15); dichotomous inflorescence branches 1(-2), i.e. 2(-4) buds possible per inflorescence $\quad \ldots$. Rhizophora apiculata B1.

BB. Style length 1.5-2.7 ( $\tilde{x}=1.9) \mathrm{mm}$; bracts and bracteoles smooth with distinct dark brown crenulate margins.

Petals slightly hairy, slightly involute and lanceolate or oblong; stamens (7-)8-11(-15); dichotomous inflorescence branches (01)1-2, i.e. (1-)2-4 buds possible pe inflorescence .. 
AA. Leaves with small reddish-brown spots evenly distributed on the undersurface (not to be confused with the slightly raised scale of infection spots).

Leaf blade usually obovate, length to width ratio $c$. 1.75; peduncle length usually greater than $2 \mathrm{~cm}$, invariably longer than the petioles in the same leafy crown; bud shape ovate, L/W ratio $c$. 1.90; stamens 8 or less; petals lanceolate, very hairy and involute; calyx lobes thin and relatively smooth; bracts and bracteoles smooth-surfaced and relatively delicate; hypocotyls mostly greater than $35 \mathrm{~cm}$ long although often consistently shorter in areas of low freshwater influence, usually possessing an acutely pointed root tip; hypocotyl collar width 7.5-13.5 $(\mathrm{x}=10.5) \mathrm{mm} \quad \ldots \ldots \ldots \ldots$. C. Rhizophora subgroup: Mangle

C. Style length 2.8-5.5 ( $\bar{x}=4.2) \mathrm{mm}$.

Buds smooth, regular and slightly ovate; mature buds usually pale yellow in colour, bracts quite distinct with dark crenulate margins; dichotomous inflorescence branches(0-)2-4(-6), i.e. (1-)4-16(-64) buds possible per inflorescence; stamens (6-)8

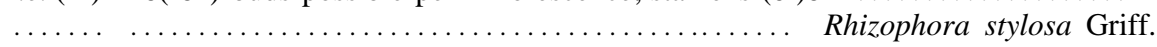

CC. Style length $0.6-2.3 \quad(\bar{x}=1.1) \mathrm{mm}$.

Buds smooth and irregularly ovate; mature buds usually remaining pale green, calyx lobes yellow as buds open; bracts minute, margins often indistinct; dichotomous inflorescence branches 0-1 (-2), i.e. 1-2 (-4) buds possibIe per inflorescence; structure unique, in some, with one or two pedicels and one sessile flower attached to the one peduncle (Fig. 4); stamens (7-) 8 Rhizophora mucronata Lamk.

\section{Descriptions of Species}

The specific descriptions coordinate all information on morphological features along with some distribution and habitat data.

\section{Rhizophora apiculata Bl.}

\section{Habit}

Multitrunked, rambling, to columnar tree to $c .25 \mathrm{~m}$ high, and to $c .85 \mathrm{~cm}$ girth (trunk girth of Rhizophoras measured just above the highest established prop root). Noted commonly in middle to upper tidal reaches (Fig. 8) of rivers and streams with constant freshwater runoff. Often extends up the tidal profile to the terrestrial fringe in the areas of higher rainfall. Associated commonly with R. stylosa and Bruguiera gymnorhiza in the middle tidal reaches. Further north (e.g. Jacky Jacky Ck) Xylocarpus granatum and X. australasicus may also be commonly noted in this association. In upstream locations commonly occurring with $R$. mucronata. Best development noted in the middle tidal reaches and mud substrate. Found also in sandy areas.

\section{Leaves (Fig, 5)}

Leaves dark green, generally flat, elliptic rather than obovate. Undersurface spots absent. Upper surface smooth, shiny. Mature leaf dimensions 7-9 - 19-0 $(\bar{x}=13.0)$ $\mathrm{cm}$ long, 3.9-8.8 $(\bar{x}=6.5) \mathrm{cm}$ wide. Mean leaf length to width ratio (L/W) c. 2.0. Petiole 1.1-3.9( $\bar{x}=2.5) \mathrm{cm}$ long. Mucronate tip 2.0-6.0 $(\bar{x}=3.7) \mathrm{mm}$ long. Leaf emergence occurring mainly from November to March; some evidence suggests a slight midwinter (dry season) occurrence in August. Leaf fall mainly over the wet summer period from October to February. Colour and shape enable trees to be distinguished from other Rhizophoras over a short distance.

\section{Reproductive Parts (Figs 4-7)}

Inflorescence with single dichotomous branch, two buds possible per inflorescence. 
Only at one location in the Moresby River (Fig. 1) have double dichotomous branches been noted. Buds robustly ellipsoidal, yellow-white, slight brown superficial fissures upon maturity, dimensions $1.1-1.6(\bar{x}=1.4) \mathrm{cm}$ long, $1.0-1.3(\bar{x}=1.0) \mathrm{cm}$ wide. Peduncle $0.3-2.1(\bar{x}=1.0) \mathrm{cm}$ long, $0.4-0.7(\sim \bar{x}=0.5) \mathrm{cm}$ wide. Bracts and bracteoles bulbous, heavily fissured, overall brown corky appearance. Petals oblong, c. $9.2 \mathrm{~mm}$ long and $2.1 \mathrm{~mm}$ wide, glabrous, membranous, not hooded or involute.

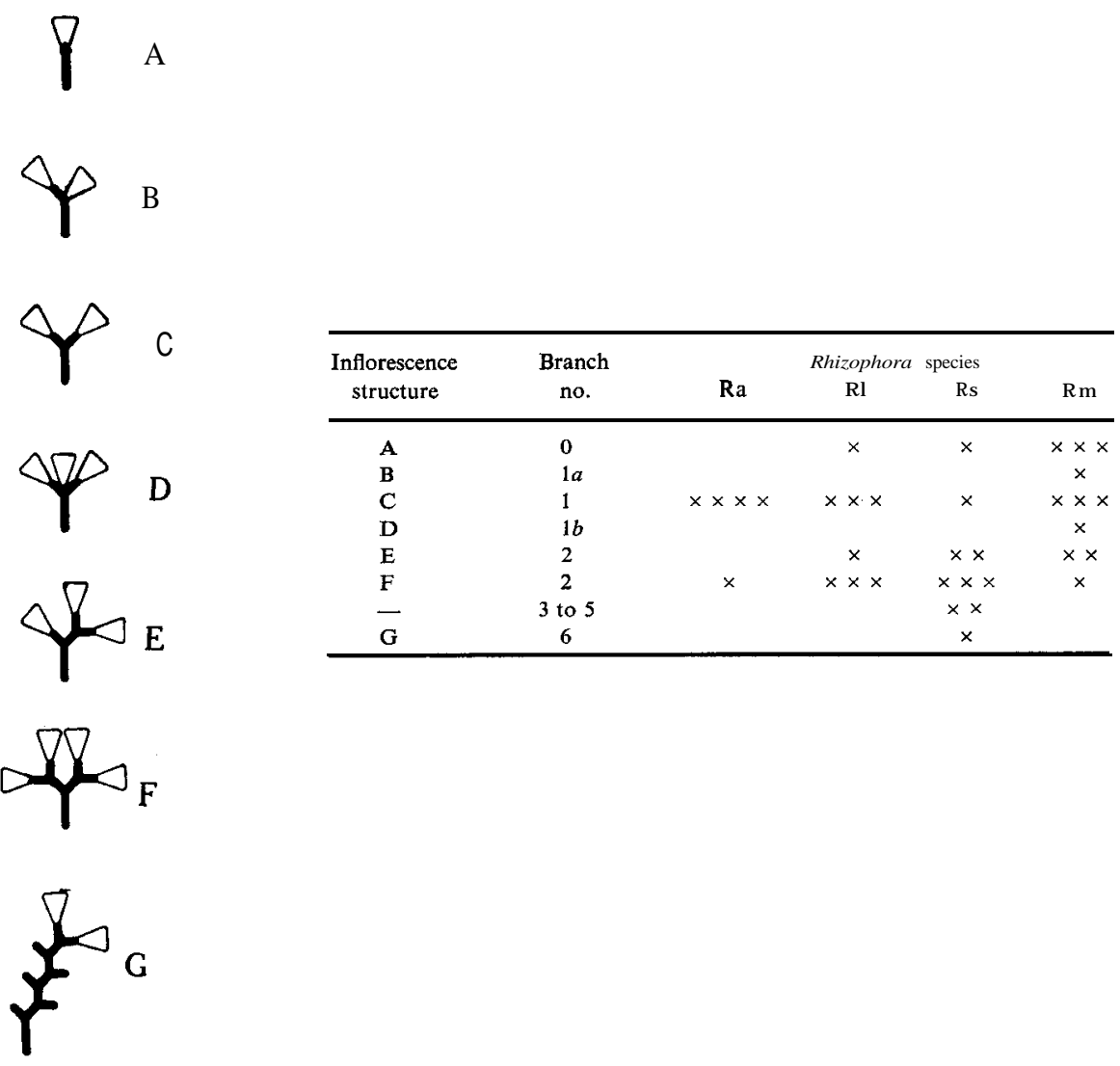

Fig. 4. Figure of inflorescence branch structure and occurrence for each Rhizophora species (occurrence: near total, $\mathrm{x} \times \mathrm{x} \times \mathrm{x}$; to infrequent, $\mathrm{x}$ ). Inflorescence branch number refers to the maximum number of joints (usually dichotomous) from peduncle to bud.

Stamens (9-) 11-12(-15). Style extremely short, $0.5-1.3(\bar{x}=0.9) \mathrm{mm}$, marked dichotomous tip. Fruits distinctly small when mature, cork-shaped, rough-textured, calyx lobes angular, dimensions (when mature hypocotyl ready to fall) 1.8-2.7 $(\bar{x}=2.2) \mathrm{cm}$ long, 1.7-2.4 ( $\bar{x}=2.1) \mathrm{cm}$ wide. Hypocotyl cylindrical, stocky, dark green, shiny, occasional raised brown lenticels, root tip rounded and blunt, dimensions 20-37 $(\bar{x}=28) \mathrm{cm}$ long, $1.2-2.0(\bar{x}=1.7) \mathrm{cm}$ at the widest point, and 0.6-0.9 $(\vec{x}=0.8) \mathrm{cm}$ wide at the 'collar'. Flower period mainly March to May, fruiting (i.e. hypocotyl fall) January to February of the following year. 


\section{Trunk and Bark}

The bark of young trees and to a lesser extent older trees (semi-mature) is characteristic: smooth, shiny, black, with occasional broad, smooth, off-white fissures, mostly vertical on the trunks and larger branches, with occasional horizontal fissures of a similar character. This bark character has been called 'crocodile skin'. Older, larger trees (and some younger ones) do not necessarily possess this bark character and have the grey fissured bark of other Rhizophoras. Multitrunked trees* are common. Prop roots are sturdy even when relatively thin.

\section{Distribution (Fig. 1 and Table 1)}

R. apiculata is not recorded for Australia by Ding Hou (1958, 1960). Jones (1971) notes that the species extends as far south as Sarina.

Distribution as determined from this study extends the limit of the species at least to Port Clinton in the south, and Cape York (10 $41^{\prime}$ S., $142^{\circ} 32^{\prime}$ E. $)$ and several southern Torres Strait Islands in the north. Overall, the species favours areas of relatively constant freshwater runoff and consequently is found in all the major estuaries and river mouths as well as on the larger mainland islands.

\section{Rhizophora lamarckii Montr.}

\section{Habit}

Multitrunked, rambling, to columnar tree c. $25 \mathrm{~m}$ high, and to $c .1 .5 \mathrm{~m}$ girth. Larger trees noted commonly projecting above the canopy of stands dominated by other Rhizophora species and B. gymnorhiza. Often found dominating higher tidal contours and lower to middle tidal reaches (Fig. 8) of rivers and streams in areas of moderate to high rainfall. In pure stands this species forms communities of mostly quite gnarled and stunted individuals achieving heights of only 3-10 m. Best development with tall columnar growth, in association with $R$. apiculata, R. stylosa, B. gymnorhiza and Ceriops tagal var. tagal. These associations commonly noted in zones of low tidal contour and mud substrate. In high tidal contour zones the species associates with $C$. tagal var. tagal.

\section{Leaves (Fig. 5)}

Leaves bright yellowish green, each side curled down near the mucronate tip, obovate to apiculate. Undersurface spots absent. Upper surfaces smooth, shiny. Mature leaf dimensions 7.7-14.8 ( $\bar{x}=11.4) \mathrm{cm}$ long, $3.2-8.2(\bar{x}=5.8) \mathrm{cm}$ wide. Mean L/W ratio c. 2.0. Petiole $1.2-3.5(\bar{x}=2.5) \mathrm{cm}$ long. Mucronate tip $2.7-6.0$ $(\bar{x}=4.4) \mathrm{mm}$ long. Leaf emergence mainly from November to February, fall from October to February. Leaf colour and shape similar to those of R. stylosa.

\section{Reproductive Parts (Figs 4-7)}

Inflorescence dichotomous branching (0-)1-2, allowing (1-)2-4 buds possible per inflorescence. Buds ellipsoid, rotund, yellow, smooth, dimensions $1.1-1.7(\bar{x}=1.5)$ $\mathrm{cm}$ long, 0.7-1.2 ( $\bar{x}=1.0) \mathrm{cm}$ wide. Peduncle $0.8-3.0(\bar{x}=\mathrm{I} .8) \mathrm{cm}$ long, 0.7-1.2

* In order to measure the girths of Rhizophora species, the position of measuring the girth was defined as the point immediately above the highest established prop root. This definition has presented the authors with trees commonly with more than one trunk. 
$(\bar{x}=1.0) \mathrm{cm}$ wide. Bracts and bracteoles smooth, and regular. Petals linear to lanceolate, c. $9.7 \mathrm{~mm}$ long and $3.2 \mathrm{~mm}$ wide, tomentose margins, slightly involute and hooded to flat. Stamens (7-) 9-1 1(-15). Style $1.5-2 \cdot 7(\bar{x}=1.9) \mathrm{mm}$. Fruit
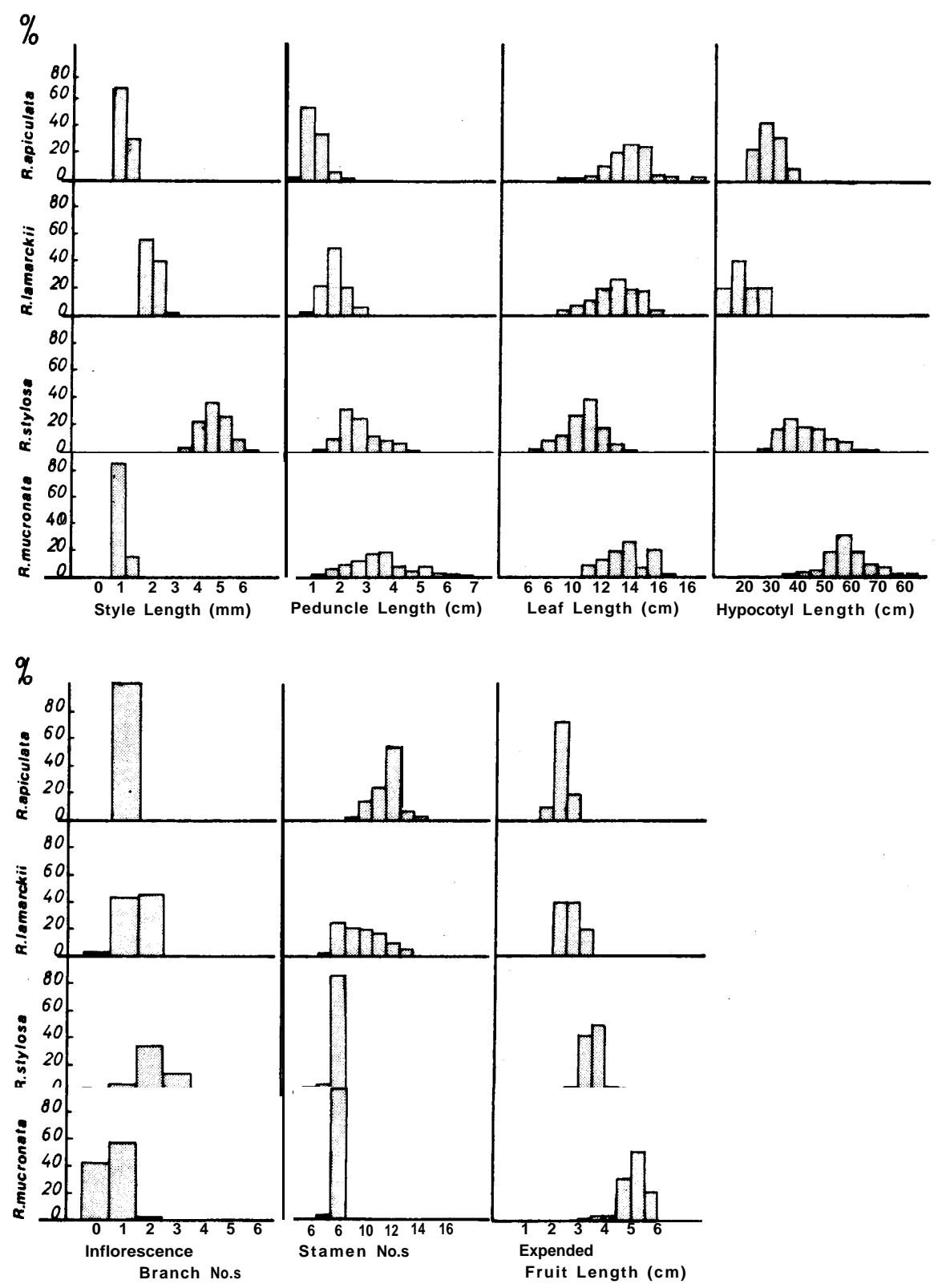

Fig. 5. Histograms of several of the components measured and counted in the study.

textured but shiny, pyriform, calyx lobes very erect, dimensions (when hypocotyl mature) 2.4-3.0 ( $\bar{x}=2.6) \mathrm{cm}$ long, $1.8-2.1(\bar{x}=1.9) \mathrm{cm}$ wide. Hypocotyls cylindrical, slender, bright green, shiny, occasional raised brown lenticels, root tip 
rounded (not pointed), dimensions 14-28 $(\bar{x}=19) \mathrm{cm}$ long, $1.0-1.3(\bar{x}=1.2) \mathrm{cm}$ at the widest point, and $0.6-0.9(\bar{x}=0.7) \mathrm{cm}$ wide at the collar. Flowering mainly from August to November, some fruiting noted in March. Reproductive development uncommonly found past the young stages of fruiting.

\section{Trunk and Bark}

Bark characters highly variable. Black, very coarse and friable to smooth, similar to 'crocodile skin' bark of $R$. apiculata. However, the majority of trees seem to have the grey fissured bark of other Rhizophora species. Multitrunked forms are common, especially within higher tidal contours.

\section{Distribution (Fig. 1 and Table 1)}

Salvoza (1936), Ding Hou (1958, 1960) and Jones (1971) fail to mention this entity for Australia, and it was not until the report of our findings by Tomlinson and Womersley (1976) that the presence of $R$. Zamarckii was recorded.

The species occurs over the complete range of this study, from Port Clinton to the tip of Cape York. In certain areas (e.g. Trinity Bay and Missionary Bay) the species is common. The southern limit in Australia is as yet still undetermined. Because the species was found in abundance within the mangroves of Port Clinton, it may be expected to extend further south.

\section{Rhizophora stylosa Griff.}

\section{Habit}

Multitrunked to columnar tree to $c .30 \mathrm{~m}$ high and to $c .1 .8 \mathrm{~m}$ girth. Common in frontal locations and downstream tidal reaches as monotypic stands. Sonneratia alba, Avicennia sp. or Camptostemon schultzii may form a thin veneer (the extent of which depends on the location) in front of these stands. In areas of low freshwater influence the species extends upstream often into the upper tidal reaches. Also in these areas the species extends up the tidal profile towards either the terrestrial fringe or bare mud areas along with $C$. tagal var. australis and scattered Avicennia sp. Best columnar tree development noted in mud substrate, but good development in sand (coral or rock) and rocks. In sheltered bays, enclaves and islands the species is found almost to the exclusion of other Rhizophoras. In these situations the canopy height to $c .8 \mathrm{~m}$. In terms of the wide range of habitats occupied and its dominance in the lower limits of the tidal forest, this species is one of the most successful tidal forest representatives.

\section{Leaves (Fig. 5)}

Leaves bright yellow-green, margin revolute, obovate. Spots on undersurface, scattered evenly, not raised, reddish brown (may be distinguished from infections and wounds by their uniformity). Upper surface smooth, shiny. Mature leaf dimensions 6.3 - $13.7(\vec{x}=10.0) \mathrm{cm}$ long, $3.8-8.0(\bar{x}=5.8) \mathrm{cm}$ wide. Mean leaf L/W ratio c. 1.7. Petiole $1.3-3.6(\bar{x}=2.4) \mathrm{cm}$ long. Mucronate tip 2.0-5 .9 $(\bar{x}=3.7) \mathrm{mm}$ long. Leaf emergence mainly from November to February, leaf fall mainly from October to February. 


\section{Reproductive Parts (Figs 4-7)}

Inflorescence branch points (0-)2-4(-6), and (1-)4-16(-64) buds possible per inflorescence. Buds widest near the base, green when immature to pale yellow as they mature, smooth, dimensions 1.3-1.8 ( $\bar{x}=1.5) \mathrm{cm}$ long, 0.7- $0.9(\bar{x}=0.8)$ $\mathrm{cm}$ wide. Peduncle $1.2-4.8(\bar{x}=2 \cdot 7) \mathrm{cm}$ long, $0.2-0.4(\bar{x}=0 \cdot 3) \mathrm{cm}$ wide. Bracts

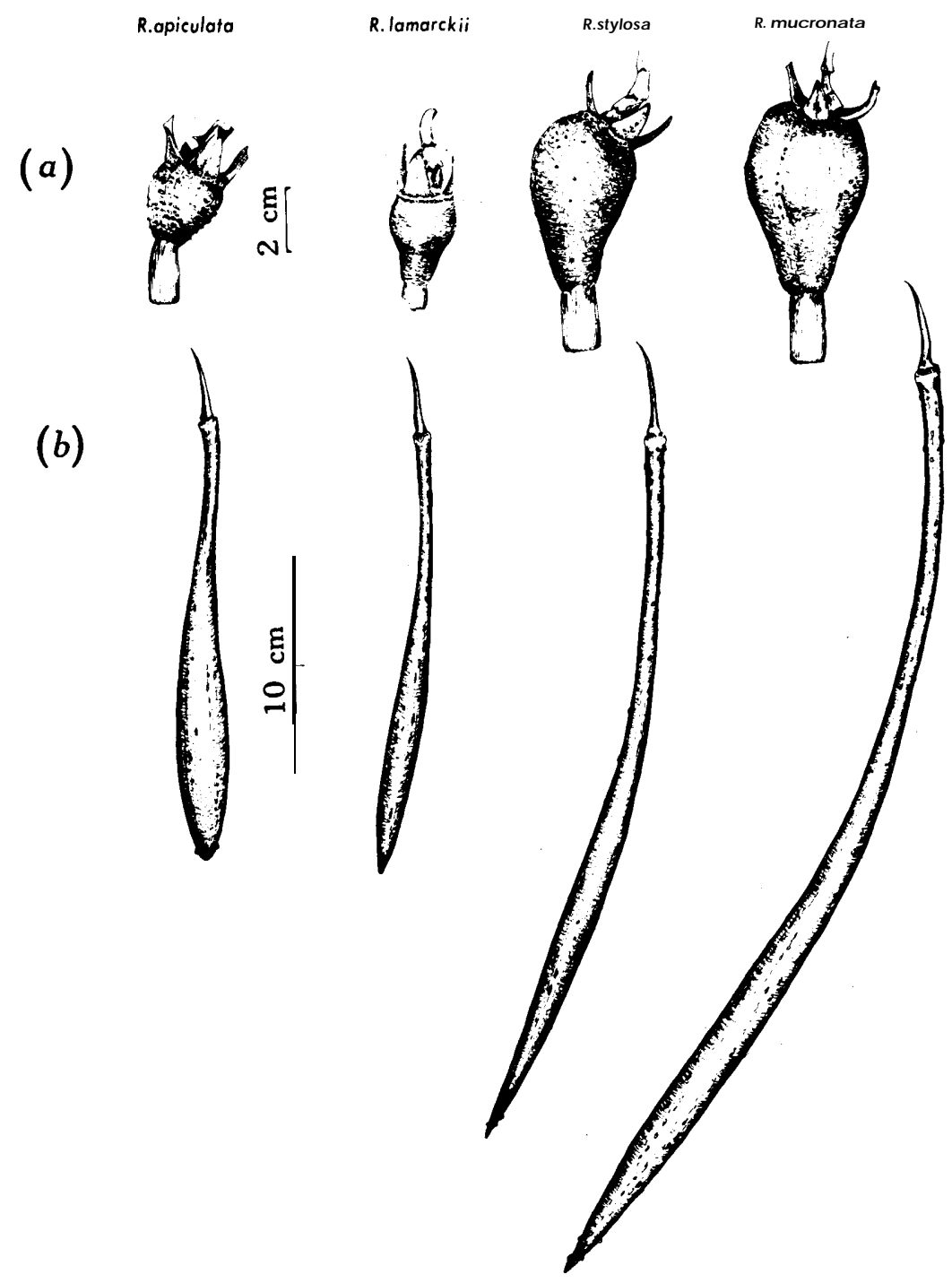

Fig. 6. Illustrations of the expended fruit (a) and hypocotyls (b), showing differences between the four Rhizophora species.

and bracteoles smooth, regular, and margins brown, crenulate. Petals lanceolate, c. $12.0 \mathrm{~mm}$ long and $3.6 \mathrm{~mm}$ wide, woolly margins, involute, hooded. Stamens (6-)8. Style terete, filiform, 2.8-5.5 ( $(\bar{x}=4.2) \mathrm{mm}$ long. Fruit pyriform, bulbous, slightly rough-surfaced, calyx lobes rounded and blunt, dimensions (when hypocotyl 
ready to fall) $2.7-4.8(\bar{x}=3 \cdot 5) \mathrm{cm}$ long, 2.1-3.2 $(\bar{x}=2.7) \mathrm{cm}$ wide. Hypocotyl cylindrical, green, smooth with irregular small brown lenticels, root tip pointed, dimensions 26-65 $(\vec{x}=42) \mathrm{cm}$ long, $1.2-2.1(\bar{x}=1.6) \mathrm{cm}$ at the widest point, and $0.8-1.4(\bar{x}=1.1) \mathrm{cm}$ wide at the collar. Flowering predominantly in March, fruiting (hypocotyl fall) mostly in February.

\section{Trunk and Bark}

Bark smooth and red-brown in seaward and exposed locations (rocky and sandy substrates), to grey fissured with smooth, pale red-brown prop roots in sheltered locations (mud substrates). Total coverage of grey fissured bark in some localities. Multitrunked trees occur in frontal areas, but more common in the upper intertidal regions.

Distribution (Fig. 1 and Table 1)

Jones (1971) records the southern limit of the species as Richmond River, N.S.W. (lat. $28^{\circ} 31^{\prime}$ S.). Ding Hou (1958) notes its occurrence in the Northern Territory but makes no mention of the Queensland populations.

In this study the species has been noted to occur from Port Clinton to the tip of Cape York and the Torres Strait Islands.

\section{Rhizophora mucronata Lamk}

\section{Habit}

Mostly columnar tree to $c .15 \mathrm{~m}$ high, and to $c .50 \mathrm{~cm}$ girth. Common in upper tidal reaches in areas of high rainfall. Notable coordinate development in both present and cleared lowland rain-forest regions (three main regions described in distribution notes). Mainly noted in frontal stands. R. apiculata, $R$. stylosa and $R$. mucronata occur in stands together. Further upstream, however, the species totally replaces $R$. stylos $a$ on the inside of stream meanders (growing edge). In these situations it can be commonly backed by B. parviflora and $R$. apiculata, and is often associated with Sonneratia caseolaris and Aegiceras corniculatum. Good development in both firm mud and black sand.

\section{Leaves (Fig. 5)}

Leaves bright green, 'floppy', margins revolute, obovate. Spots reddish brown, evenly scattered over the undersurface. Upper surface smooth, shiny. Mature leaf dimensions $10.5-16.5(\bar{x}=13.3) \mathrm{cm}$ long, and 5.1-10.6 ( $\bar{x}=7.4) \mathrm{cm}$ wide*. Mean $\mathrm{L} / \mathrm{W}$ ratio $c$. 1.8. Petiole 2.1- $4.8(\bar{x}=3.6) \mathrm{mm}$ long. Mucronate tip $2.0-5.0$ $(\bar{x}=3.6) \mathrm{mm}$ long. Although not observed, leaf emergence is expected to be similar to R. stylosa. It would be expected, however, that the species would be more sensitive to the incidence of rainfall and freshwater runoff. Leaf fall expected also to be similar to $R$. stylosa.

\section{Reproductive Parts (Figs 4-7)}

Inflorescence dichotomous branching $0-1(-2)$, and 1-2(-4) buds possible per inflorescence. At least two unique forms ( $1 a$ and $1 b$, Fig. 4) of single branched inflorescence included, with up to $13 \%$ frequency of occurrence. Buds wider at the base, irregularly obovate, mature buds pale yellowish green, smooth, dimensions

\footnotetext{
* Since completion of the study leaves ofgreater dimensions, up to $21.1 \mathrm{~cm}$ long and $11.4 \mathrm{~cm}$ wide, have been Iocated in the Claudie River and elsewhere.
} 
$1.2-1.8(\sim x=1.5) \mathrm{cm}$ long, $0.7-1.0(\sim x=0.8) \mathrm{cm}$ wide. Peduncle $1.2-6.6(\sim x=3.5)$ $\mathrm{cm}$ long, and 2.3-4.8 ( $\bar{x}=3.2) \mathrm{cm}$ wide. Bracts and bracteoles regular, smooth, minute, margins indistinct. Petals lanceolate, $c .10 .2 \mathrm{~mm}$ long and $3.1 \mathrm{~mm}$ wide, woolly, involute, and hooded. Stamens (7-)8. Style short, 0.6-2.3 ( $\bar{x}=1.1) \mathrm{mm}$ long, terete, and mounted on the highly conical ovary. Fruits pyriform, strongly contracted about the distal end with slight but characteristic vertical grooves in the proximal bulbous portion, slightly rough, calyx lobes rounded and blunt, dimensions (hypocotyls ready to fall) $3.4-6.0(\bar{x}=5.1) \mathrm{cm}$ long, and $1.9-3.7(\bar{x}=3.2) \mathrm{cm}$

(a)

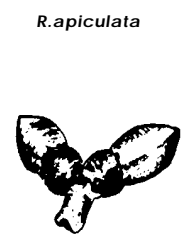

(b)
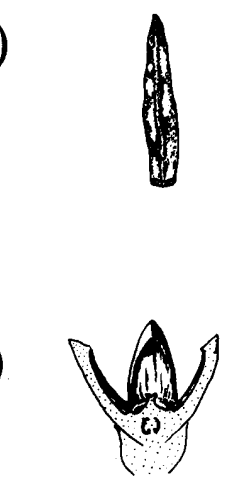

(c)
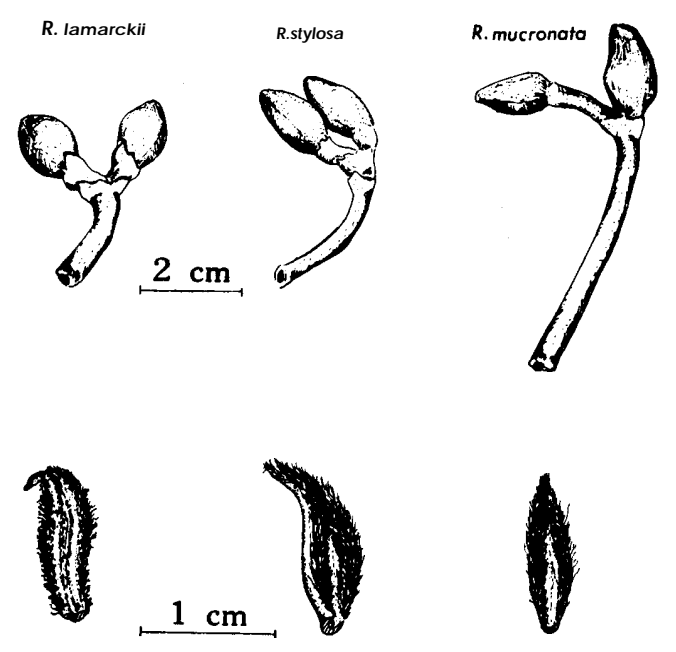

(d)
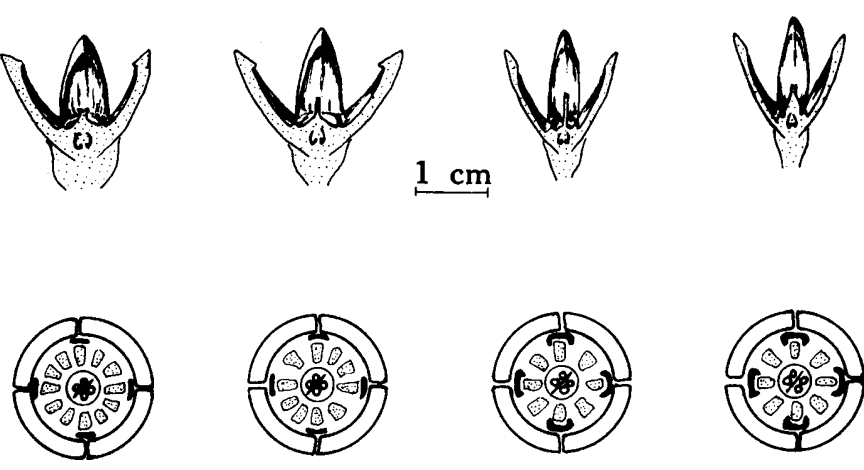

Fig. 7. Illustrations of the buds and flower parts, showing differences between the four Rhizophora species. Illustrations include inflorescences (a), petals (b), open bud sections with stamens and petals removed $(c)$, and floral diagrams $(d)$.

wide. Hypocotyls cylindrical, elongate, green, smooth with brown lenticels, root tip pointed, dimensions $40-80(\bar{x}=59) \mathrm{cm}$ long, $1.2-2.1(\bar{x}=1.7) \mathrm{cm}$ at the widest point, and $0.8-1.2(\bar{x}=1.0) \mathrm{cm}$ wide at the collar. Flowering period August to December, fruiting (hypocotyl fall) mostly from November to March for fruit set at least 12 months previously. More precise flower and fruiting period data are not yet available for this species. 


\section{Trunk and Bark}

Bark grey to dark grey and heavily fissured. Multitrunked trees not noted for this species, but this type of development, common in the other Rhizophoras, should not be discounted.

\section{Distribution (Fig. 1 and Table 1)}

Jones (1971) lists distribution from Cape York to Repulse Bay. Ding Hou (1958) mentions its occurrence in northern Australia. However, as earlier observations of this species may not have been reliably based because of the inadequacies of the Rhizophora keys in the Australian region, distributions listed to date must be suspect. $R$. mucronata, as now described, exists in three main areas of this study. These three areas include Jardine River to Barnia Creek, at Cape York (three sites), Harmer Creek to Lockhart River (five sites), and Morgan/McIvor Rivers to Deluge Inlet (southern end of Hinchinbrook I.) (15 sites). The distribution appears discontinuous and correlated with areas of high rainfall, and often the species is associated with terrestrial lowland rain-forest.

\section{Discussion}

Recognizing that the taxonomic status of the genus Rhizophora and of its component species was inadequately documented, Tomlinson (1978) recently attempted a fresh analysis. His treatment provides a most useful global perspective but has been found difficult to apply on a regional basis. The account presented here is an attempt to clarify the entities at least for the Australian east coast, on the basis of a large body of information accumulated during the course of estuarine productivity studies.

Since most diagnostic characters of the four entities appear to overlap (Fig. 5) and thus are non-definitive, Dr W. Williams suggested the use of classificatory analyses to assist in resolving difficulties in identification. This analysis has shown that differentiation of species is possible, even from leaf characters. Furthermore, association of the different species to each other is clearly shown to depend very much on the set of characters studied. While $R$. Zamarckii always emerges intermediate between $R$. stylosa and R. apiculata, R. mucronata displays association with each of the other three species, and most closely with $R$. stylosa. R. apiculata has closest associations with $R$. lamarckii. In fact, this association was the 'strongest' found. Overall associations of the species, based on characters used in this study, are summarized in Fig. 8. Distinct identities have been confirmed even when consideration of individual characters revealed marked overlap (Fig. 2b). Classificatory analysis has thus shown that the mean measurement of 30 components of each of a small group of characters (at least six) of an individual tree enable that tree to be identified over the limited geographical range. The optimal requirement of this type of analysis is that data be available from many trees and sites.

The presence or absence of spots (conspicuous cork warts) on the leaf undersurface has been a most useful field character in the recognition of the north-eastern Australian Rhizophora species, hence this character's dominant role in the proposed key. Our experience, from the monthly sorting of mixed Rhizophora litter over 3 years, is that the spot character is consistent and would be just as useful in the identification of herbarium specimens. This observation has been further substantiated by an increasing 
herbarium (AIMS) collection from north-eastern Queensland. Spots on dried leaves, however, are less well defined, and leaf infections can often cause them to be partially obscured. Identification during the litter study was aided by the use of the different leaf surface textures and variations of leaf shape. In regard to the presence of this character in the Indo-Malesian region, Salvoza (1936) noted underleaf spots for $R$. stylosa (i.e. his $R$. mucronata var. styIosa) but did not record it for $R$. mucronata. More recently Ding Hou (1958) utilized underleaf 'scattered black dots' to distinguish between a grouping of Rhizophora, Bruguiera and Carallia, all with dots, and Ceriops and Kandelia without dots; this account describes Rhizophora leaves as 'usually black-dotted below'. Others make no mention of this character (Tomlinson and Womersley 1976; Tomlinson 1978). However, for the Australian east coast, Jones (1971) mentions the presence of reddish brown glands for both $R$. stylosa and $R$. mucronata. This character is not necessarily expected to apply throughout IndoMalesia; in fact, present indications are that spotted leaves are noted on $R$. apiculata at locations as close as New Guinea (CANB 71448 from Murak Lagoon, P.N.G.).

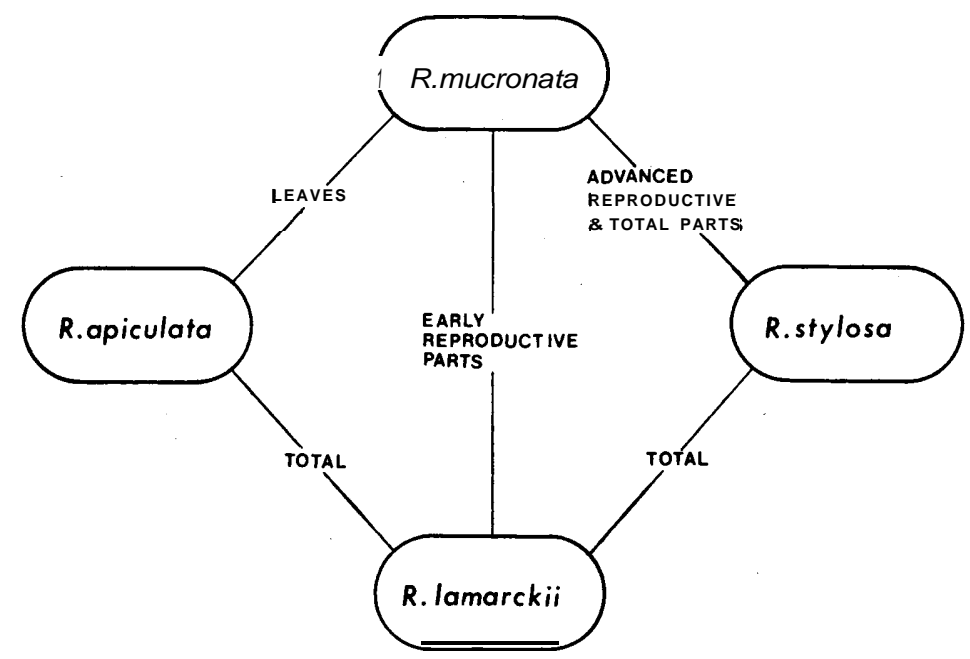

Fig. 8. Schematic summary of the six classificatory analyses performed. Links between species indicate closest affinities along with the responsible components as described in Table 2.

Hence, in order to make this study comparable with the studies in Indo-Malesia, this character was not used in the classificatory analyses, so as not to bias the results towards the groupings of the Mangle type and Aërope type (as noted by Salvoza 1936). None the less, the analysis has shown strongly that, overall, these groupings persist. In summing up, the literature appears vague in regard to the presence of spots, and this is in marked contrast to the present findings on the north-east Queensland coast. Further work is required to substantiate whether the use of underleaf spots (or cork warts) in Rhizophora identification applies throughout Australia and elsewhere.

Although $R$. lamarckii is a distinct form, and shows close phenological association with both $R$. stylosa and $R$. apiculata, its low fertility suggests that this species is 
a hybrid. However, its pattern of distribution, in that it may be found growing in areas where few other Rhizophoras occur, raises the question of the actual means of dispersal and obvious success of this species. Observations by Guppy (1906) in Fiji on the infertile, putative hybrid of $R$. stylosa and $R$. samoensis (var. of $R$. mangle noted by Tomlinson 1978), $R$. selala, suggest that seedlings of the putative hybrid are derived from one of the 'parents', $R$. stylosa. No such findings have been made for $R$. Zamarckii, and to date the evidence for the 'recent' hybrid origin is shown only by its low fertility, its intermediate characters, and the observation that it exists in areas where both putative parents also occur (even if in low numbers).

In regard to geographical distribution, R. stylosa is the most widespread and continuous, with R. apiculata second, then closely $R$. Zamarckii, and finally R. mucronata which is discontinuously distributed in north-eastern Australia. Although the limiting factors appear diverse, freshwater influences are clearly important, especially for $R$. mucronata (Table 1, rainfall data). In this region it would appear that tolerance to lack of fresh water increases with geographical continuity of the four species. Local distribution in the rivers where all four species occur presents us with a similar order of species (Fig. 9).

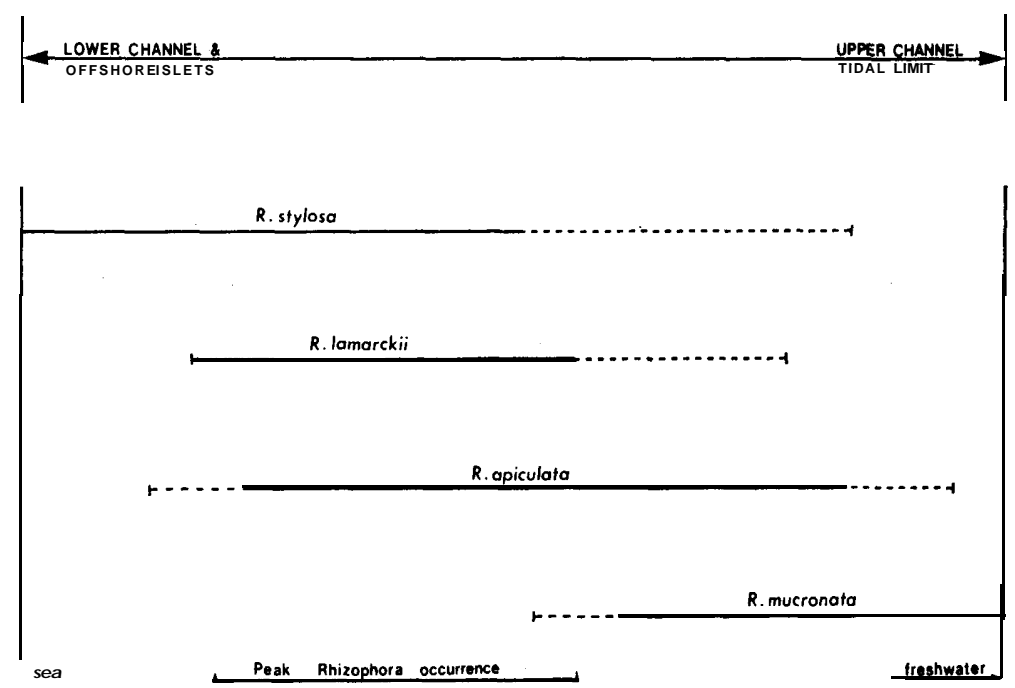

Fig. 9. Schematic diagram representing the local distribution of the four Rhizophora species as found between the lower estuarine limit (sea), to the upper tidal limits (freshwater). Modelled on two estuaries-the Hull River and Deluge Inlet.

Phenological character and distribution of both $R$. Zamarckii and $R$. mucronata clearly define these entities in north-eastern Australia as distinct from the IndoMalesian forms. This is especially the case for R. mucronata, which requires further taxonomic study to reveal whether it warrants classification as a separate species.

More extensive knowledge of the genus is necessary for correlation with microedaphic conditions influencing population groups along the northern Australian coastline, Only with this information can a fully reliable assessment be made of the Rhizophora entities, their environmental limits and their ecological significance. 


\section{Acknowledgments}

We extend our sincere appreciation of the criticism, advice and expertise offered by Dr W. T. Williams (CSIRO, Davies Laboratory, Townsville, Qld), and Dr B. Jackes (Botany Department, James Cook University of North Queensland).

\section{References}

Burr, E. J. (1968). Cluster sorting with mixed character types. I. Standardisation of character values. Aust. Comput. J. 1, 97-9.

Burr, E. J. (1970). Cluster sorting with mixed character types. II. Fusion strategies. Aust. Comput. J. 2, 98-103.

Ding Hou (1958). 1. Rhizophora. In 'Flora Malesiana' Ser. I, Vol. 5(4), pp. 448-57.

Ding Hou (1960). A review of the genus Rhizophora. Blumea 10(2), 625.

Gower, J. C., and Ross, G. J. S. (1969). Minimum spanning trees and single linkage cluster analysis. Appl. Stat. 18, 54-64.

Guppy, H. B. (1906). 'Observations of a Naturalist in the Pacific between 1896 and 1899.' Vol. II, Plant Dispersal. (Macmillan: London.)

Jones, W. T. (1971). Field identification and distribution of mangroves in eastern Australia. $Q d$ Nat. 20(1/3), 35-51.

Mumme, A. W. (1969). In 'Queensland Year Book', no. 30, p. 21. (C'wealth Bur. Census and Statistics: Brisbane.)

Salvoza, F. M. (1936). Rhizophora. Nat. Appl. Sci. Bull. Univ. Philipp. 5, 179-237.

Semeniuk, V., Kenneally, K. F., and Wilson, P. G. (1978). 'Mangroves of Western Australia.' (West. Aust. Naturalists' Club: Perth.)

Stace, C. A. (1966). The use of epidermal characters in phylogenetic considerations. New Phytol. 65, 304-18.

Tomlinson, P. B. (1978). Rhizophora in Australasia-some clarification of taxonomy and distribution. J. Arnold Arbor. Harv. Univ. 59, 156-69.

Tomlinson, P, B., and Womersley, J. S. (1976). A species of Rhizophora new to New Guinea and Queensland, with notes relevant to the genus. Contrib. Herb. Aust. 19, 1-10.

Williams, W. T. (1971). Principles of clustering. Annu. Rev. Ecol. Syst. 2, 303-26. 